\title{
The phytochemical and bioactivity profiles of wild Calluna vulgaris L. flowers
}

\author{
Francisca Rodrigues ${ }^{\mathrm{a}}$, Teresa Moreira ${ }^{\mathrm{a}}$, Diana Pinto ${ }^{\mathrm{a}}$, Filipa B. Pimentel ${ }^{\mathrm{a}}$, Anabela S.G. Costa $^{\mathrm{a}}$, \\ M. Antónia Nunes ${ }^{\mathrm{a}}$, Tânia Gonçalves Albuquerque ${ }^{\mathrm{a}, \mathrm{b}}$, Helena S. Costa ${ }^{\mathrm{a}, \mathrm{b}}$, \\ Ana Palmeira-de-Oliveira $^{c, d}$, Ana I. Oliveira ${ }^{\mathrm{e}}$, Stefania Sut ${ }^{\mathrm{f}}$, Stefano Dall'Acqua ${ }^{\mathrm{f}}$, M. Beatriz P.P. Oliveira ${ }^{\mathrm{a}}$ \\ ${ }^{a}$ LAQV/REQUIMTE, Faculty of Pharmacy, University of Porto, Porto, Portugal \\ ${ }^{\mathrm{b}}$ Research and Development Unit, Department of Food and Nutrition, National Institute of Health Dr. Ricardo Jorge, Lisbon, Portugal \\ ${ }^{c}$ CICS-UBI - Health Sciences Research Centre, University of Beira Interior, Covilhã, Portugal \\ ${ }^{\mathrm{d}}$ Labfit-HPRD: Health Products Research and Development Lda, Covilhã, Portugal \\ e Núcleo de Investigação e Informação em Farmácia, Centro de Investigação em Saúde e Ambiente, Escola Superior de Tecnologia de Saúde do Porto, Instituto Politécnico do \\ Porto, Porto, Portugal \\ ${ }^{\mathrm{f}}$ Department of Pharmaceutical and Pharmacological Sciences, University of Padova, Via Marzolo 5, Padova 35121, Italy
}

\section{A B S T R A C T}

\begin{abstract}
The nutritional composition of Calluna vulgaris flowers as well as the phytochemical profile, antioxidant (DPPH and FRAP assays), antimicrobial and cytotoxic (in human immortalized non-tumorigenic keratinocyte and fibroblasts) activities of aqueous, hydroalcoholic and ethanolic extracts were evaluated. A high content of fiber and carbohydrates (75\%) and the prevalence of $\alpha$-tocopherol as vitamer deserves attention. Linolenic (35\%), linoleic $(27 \%)$ and palmitic (21\%) acids were the most abundant fatty acids. Qualitative and quantitative analysis by LC-MS and ${ }^{1}$ NMR indicated high levels of quercetin, kaempferol and myricetin derivatives as well as procyanidins. The hydro-alcoholic extract displayed the highest antioxidant activity and total phenolics (TPC) and flavonoid contents (TFC). No adverse effects on cells were observed until a concentration of $100 \mu \mathrm{g} / \mathrm{mL}$ and a good antimicrobial activity was reported against $S$. epidermidis and $S$. aureus with the hydro-alcoholic extract. The data obtained demonstrated that wild plants like heather, although not being a common nutritional re-ference, can be used in an alimentary base as a source of bioactive compounds, namely antioxidants.
\end{abstract}

Keywords: Calluna vulgaris (L.) hull; Natural antioxidants; Bioactivity;Phenolic compounds

\section{Introduction}

Calluna vulgaris (L.) hull (Ericaceae) is a wild plant of European flora, usually known as heather, being mainly present in south Europe and well adapted to severe drought conditions (Arabuli, Connor, \& Kvavadze, 2007). Heather is a small green shrub or sub-shrub with 20 to $100 \mathrm{~cm}$, presenting grey-brown ascending branches. The leaves are persistent, short and directly inserted in the base of the stem. Flowers, with reduced pedicels, are arranged in terminal bunches unilaterally, presenting pink or lilac colour. The flowering process occurs from May to October and the fruit ripens in autumn, with no ornamental features. In popular medicine, $C$. vulgaris flowers are used to prepare different types of infusions, particularly sedatives, diuretic and disinfectant (Saaby, Rasmussen, \& Jäger, 2009). However, in 2009 the European Food Safety Authority (EFSA) released a scientific opinion sustaining the absence of relation between $C$. vulgaris and the normal mood balance or normal ability to fall asleep (EFSA, 2010). Nonetheless, heather is well popular among old population and recently a growing interest to provide data on nutritional value and bioactive composition has been observed. For example, Garcia-Risco et al. reported its high content in triterpenes, mainly oleanolic and ursolic acids, extracted with supercritical $\mathrm{CO}_{2}$ (García-Risco et al., 2015). Despite these promising information, there is scarcity of literature about the phytochemical composition of $C$. vulgaris flowers as well as its antioxidant and antimicrobial activity. Indeed, the macronutrients composition, fatty acids and vitamin E profile and the cell viability effects are not described. This work also aimed to appraise the use of heather as a food ingredient and health-promoting plant.

\section{Materials and methods}

\subsection{Chemicals and reagents}

Tocopherols ( $\alpha, \beta, \Upsilon$ and $\delta$ ) and tocotrienols $(\alpha, \beta, \Upsilon$ and $\delta$ ) were 
purchased from Calbiochem (La Jolla, California, USA) and tocol (internal standard, IS) was obtained from Matreya Inc. (Pennsylvania, USA). Butylated hydroxytoluene (BHT) was from Sigma-Aldrich (Madrid, Spain). Supelco 37 Component FAME Mix and boron trifluoride-methanol (14\%) were obtained from Sigma-Aldrich (St. Louis, USA). Methanol was from VWR International (Leveun, Belgium). Ascorbic acid, 1,1-diphenyl-2-picrylhydrazyl (DPPH) free radical, catechin, Folin-Ciocalteu's reagent, gallic acid, iodine, 6-hydroxy-2,5,7,8tetramethylchroman-2-carboxylic acid, glycerol, trolox and butylated hydroxyanisole (BHA) were all purchased from Sigma- Aldrich (Steinheim, Germany). Ethanol reagent grade, sodium acetate, sodium carbonate decahydrate, sodium nitrite, aluminium chloride, anhydrous sodium sulfate and sodium hydroxide were purchased from Merck (Darmstadt, Germany).

HPLC-grade acetonitrile and 1,4-dioxane were from Fluka (Madrid, Spain). HPLC grade $n$-hexane, methanol, dimethyl sulfoxide (DMSO) were from Merck (Darmstad, Germany). Purified water was obtained from a Milli-Q water purification system (Millipore, Bedford, MA, USA). Vitek-2 identification cards were from Biomerieux (Crappone, France). Brain Heart Infusion, Nutrient agar, Sabouraud dextrose agar and Mueller Hinton broth were purchased from Difco Laboratories (USA). RPMI was from Biochrom (Berlin, Germany). Dulbecco's modified Eagle's medium (DMEM) with GlutaMAX ${ }^{\mathrm{TM}-\mathrm{I}}$, fetal bovine serum (FBS), streptomycin, penicillin and amphotericin $B$ were from Invitrogen (Carlsbad, CA, USA). MTT assay kit (CellTiter $96^{\circ}$ Non-Radioactive Cell Proliferation Assay) was purchased from Promega (Madison, WI, USA).

\subsection{Samples}

C. vulgaris flowers were collected during October 2016 in Moreira de Cónegos, Portugal (GPS: 41.384555, - 8.334941). Ten shrubs were selected, collecting manually 50 flowers from each one. Flowers were separated from the rest of the plant and stored in plastic containers at $4{ }^{\circ} \mathrm{C}$ until further use.

\subsection{Macronutrient analysis}

Moisture content was instrumentally determined using a moisture analyser (SMO 01, Scaltec Instruments, Germany). The ash content was determined by incineration according to 923.03 AOAC method (AOAC, 2012a). Protein content (nitrogen conversion factor 6.25) was evaluated using the Kjeldahl procedure (AOAC, 2012c) and dietary fiber by an enzymatic gravimetric method, according to the AOAC procedure (AOAC, 2012d). Total fat was evaluated by Soxhlet extraction method (AOAC, 2012b) and carbohydrate content by difference (Tontisirin, MacLean, \& Warwick, 2003). All analyses were performed in triplicate and the results expressed as $\mathrm{g} / 100 \mathrm{~g}$ of sample.

\subsection{Qualitative and quantitative vitamin E evaluation}

The lipid fraction of $C$. vulgaris, obtained by Soxhlet extraction with petroleum ether $(2.5 \mathrm{~h})$, was used to determine the vitamin $\mathrm{E}$ profile. Briefly, $20 \mathrm{mg}$ of oil were diluted in $1 \mathrm{~mL}$ of $n$-hexane with $20 \mu \mathrm{g} / \mathrm{mL}$ of tocol (Internal Standard). The chromatographic analysis was carried out in an HPLC integrated system (Jasco, Tokyo, Japan) equipped with two PU-980 pumps, an AS-2057 automated injector, and a MD-2015 multi-wavelength diode array detector (DAD) coupled to a fluorescence detector FP-2020, programmed for excitation at $290 \mathrm{~nm}$ and emission at $330 \mathrm{~nm}$. The chromatographic separation of compounds was achieved on a normal phase Supelcosil ${ }^{\mathrm{TM}}$ LC-SI column $(3 \mu \mathrm{m} ; 75 \times 3.0 \mathrm{~mm}$; Supelco, Bellefonte, PA, USA) according to Alves et al.(Alves et al., 2009). The injection volume was $20 \mu \mathrm{L}$, eluted with $1.8 \%$ 1,4-dioxane in $n$-hexane $(v / v)$ at a flow rate of $0.8 \mathrm{~mL} / \mathrm{min}$ at room temperature. Chromatographic data were analyzed using a JASCO-Chrom NAV Chromatography Software (Jasco, Tokyo Japan). Compounds were quantified based on the internal standard method, using the fluorescence signal response of each standard converted to concentration units through the calibration curves. These were obtained by preparing a standard stock solution containing individual compounds $(\alpha-, \beta$-, $\gamma$ - and $\delta$-tocopherol and $\alpha$-, $\beta$-, $\gamma$ - and $\delta$-tocotrienol) in $n$-hexane, subsequently diluted to $25,18.75,12.5,6.25,2.5$ and $1.25 \mu \mathrm{g} / \mathrm{mL}$. Each solution contained $20 \mu \mathrm{L}$ of tocol (IS, $1 \mathrm{mg} / \mathrm{mL}$ ). The compounds were identified based on their UV/VIS spectra and by the comparison of their retention times with those of the standards. Results were expressed as $\mathrm{mg} / 100 \mathrm{~g}$ of sample.

\subsection{Fatty acids profile}

The fatty acids present in the lipidic fraction were derivatized to form the corresponding fatty acid methyl esters (FAMEs) (Fernandes et al., 2012). FAMEs were prepared by addition of $0.5 \mathrm{M}$ methanolic $\mathrm{KOH}$ solution to the sample. The mixture was heated at $100{ }^{\circ} \mathrm{C}$ for $10 \mathrm{~min}$ and boron trifluoride-methanol $(14 \% ; 2 \mathrm{~mL})$ added followed by heating at $100{ }^{\circ} \mathrm{C}$ for $30 \mathrm{~min}$. After cooling down, $2 \mathrm{~mL}$ of deionized water and $5 \mathrm{~mL}$ of $n$-hexane were added to the sample. The solution was centrifuged ( $3000 \mathrm{rpm}, 5 \mathrm{~min}$ ) and the supernatant transferred. Anhydrous sodium sulfate was used to eliminate remaining water. The mixture was vortexed and centrifuged ( $3000 \mathrm{rpm}, 5 \mathrm{~min}$ ) and the upper layer transferred to an injection vial.

FAMEs separation was performed in a gas chromatograph (GC) Shimadzu GC-2010 Plus (Shimadzu, Tokyo, Japan) coupled with a split/splitless Shimadzu AOC-20i auto-injector (Shimadzu, Tokyo, Japan) and a flame ionization detector (FID) (Shimadzu, Tokyo, Japan). Helium was the carrier gas at a flow rate of $40 \mathrm{~mL} / \mathrm{min}$. A CP-Sil 88 silica capillary column for FAME $(50 \mathrm{~m} \times 0.25 \mathrm{~mm}$ i.d, $0.20 \mu \mathrm{m}$ film thickness; Varian, Middelburg, Netherlands) was used. The temperature program was as follows: $120^{\circ} \mathrm{C}(5 \mathrm{~min})$, programmed to increase to $220^{\circ} \mathrm{C}$ at $3^{\circ} \mathrm{C}$ per min, and a constant temperature of $220^{\circ} \mathrm{C}$ during $10 \mathrm{~min}$; injector and detector temperatures were 250 and $270^{\circ} \mathrm{C}$, respectively. A split ratio of 1:25 was used and the injection volume was $1.0 \mu \mathrm{L}$. FAMEs were identified by comparison with a standard mixture (FAME 37, Supelco). Data were analyzed using the Shimadzu software GC Solution (Shimadzu, Tokyo, Japan) based on the relative peak areas. Results were expressed in relative percentage of each fatty acid.

\subsection{GC-MS identification of nonadecane}

A gas chromatography-mass spectrometry (GC-MS) analysis was performed in an Agilent Technologies $6890 \mathrm{~N}$ Chromatograph coupled to a $5973 \mathrm{~N}$ mass selective detector and equipped with a HP-5MS ( $30 \mathrm{~m} \times 0.25 \mathrm{~mm}$ i.d., $0.25 \mu \mathrm{m}$ film thickness) column (Agilent Technologies, Santa Clara, CA, USA). The carrier gas was helium at a flow rate of $1 \mathrm{~mL} / \mathrm{min}$ with an average velocity of $39 \mathrm{~cm} / \mathrm{s}$. The oven temperature program was: $60^{\circ} \mathrm{C}(1 \mathrm{~min}), 17^{\circ} \mathrm{C} / \mathrm{min}$ to $180^{\circ} \mathrm{C}(28 \mathrm{~min})$, and $4^{\circ} \mathrm{C} / \mathrm{min}$ to $230^{\circ} \mathrm{C}(18 \mathrm{~min})$; total run time: $68 \mathrm{~min}$; head pressure $18 \mathrm{psi}$ and injector temperature $240^{\circ} \mathrm{C}$. MS was operated in the positive ion mode, with an ionization voltage of $70 \mathrm{eV}$. The MS data were obtained in full scan mode $(\mathrm{m} / \mathrm{z} 50-700)$.

\subsection{Identification of phenolic compounds by qualitative and quantitative analysis by ${ }^{1} H$ NMR and LC-UV-MS}

${ }^{1} \mathrm{H}$ NMR were acquired using a Bruker Avance III instrument $(400,13 \mathrm{MHz})$. The sample was dissolved in deuterated methanol. Solvent suppression sequence using presaturation was used to acquire samples to delete water signal. LC-MS analysis were performed using an Agilent 1260 chromatographic system equipped with diode array detector and Varian MS 500 Ion trap. As stationary phase an Agilent C-18 Eclipse column $3.00 \times 150 \mathrm{~mm}(3.5 \mu \mathrm{m})$ was used. The eluents were water $1 \%$ formic acid (A) and acetonitrile (B). Gradient elution started from $10 \%$ B going in $30 \mathrm{~min}$ to $100 \% \mathrm{~A}$, then isocratic for $5 \mathrm{~min}$ and equilibration time to $90 \%$ A until $40 \mathrm{~min}$. The flow rate was $400 \mu \mathrm{L} /$ 
min. After column, the liquid was equally splitted with a "T" connector to diode array detector and MS. Spectra were acquired in the range $100-2000 \mathrm{Da}$ in negative ion mode. To generate fragmentation of most intense ion species the turbo data detection scanning (tdds) function of the instrument was used. The MS parameters were the following: drying gas temperature $310^{\circ} \mathrm{C}$, drying gas pressure $25 \mathrm{psi}$, nebulized $30 \mathrm{psi}$, capillary $100 \mathrm{~V}$, needle $4500 \mathrm{~V}$, shield $500 \mathrm{~V}$, RF loading $80 \%$. Quantification of phenolic constituents was obtained with the method of calibration curve: rutin was used as external standard for quercetin derivatives; kaempferol was used for other flavonoid derivatives; procyanidin B1 was used for procyanidin derivatives. Standards were used in the range $0.5-100 / \mathrm{mL}$ at four different concentration. Calibration curves were $\mathrm{Y}=144,232 X+112 \quad\left(R^{2}=0.9998\right)$ for rutin, $\mathrm{Y}=10,234 X+27 \quad\left(R^{2}=0.9998\right) \quad$ for kaempferol and $\mathrm{Y}=92,543 X+48\left(R^{2}=0.9997\right)$ for procyanidin.

\subsection{Extracts preparation}

C. vulgaris flowers were milled to particle size of approximately $0.1 \mathrm{~mm}$ using an A11 basic analysis mill (IKA Wearke, Staufen, Germany) and stored in plastic containers at $4{ }^{\circ} \mathrm{C}$ until extraction. Samples $(1 \mathrm{~g})$ were subjected to maceration for $30 \mathrm{~min}$ at $50{ }^{\circ} \mathrm{C}$ with $20 \mathrm{~mL}$ of distilled water, ethanol:water (1:1) or ethanol, according to Rodrigues et al. (Rodrigues et al., 2013). Extracts were filtered through Whatman no. 1 filter paper, concentrated under vacuum at $37^{\circ} \mathrm{C}$ till dryness or lyophilized (water extract) and kept under refrigeration $\left(4{ }^{\circ} \mathrm{C}\right)$ prior to use. For analysis extracts were reconstituted with the same solvent. Afterwards, extracts were characterized regarding total phenolic content (TPC) and total flavonoid content (TFC), antioxidant capacity, cell viability and antimicrobial properties.

\subsubsection{Determination of total phenolic content (TPC)}

TPC was determined spectrophotometrically according to the Folin-Ciocalteu procedure (Singleton \& Rossi, 1965) with minor modifications (Alves et al., 2010). The absorbance was determined at $765 \mathrm{~nm}$ using a Synergy HT Microplate Reader (BioTek Instruments, Inc., Winooski, VT, USA). A calibration curve was prepared with gallic acid to obtain a correlation between sample absorbance and standard concentration (linearity range $=5-100 \mu \mathrm{g} / \mathrm{mL}, R^{2}>0.997$ ). The TPC of the extracts was expressed as $\mathrm{mg}$ of gallic acid equivalents (GAE) per gram of plant material on dry weight basis (dw).

\subsubsection{Determination of total flavonoid content (TFC)}

TFC was determined by a colorimetric assay based on the formation of flavonoid-aluminium compound according to Rodrigues et al. (Rodrigues et al., 2013). The absorbance was read at $510 \mathrm{~nm}$ using the Synergy HT Microplate Reader. Catechin was used as reference to plot the standard curve (linearity range: $5-400 \mu \mathrm{g} / \mathrm{mL}, R^{2}>0.999$ ). TFC was expressed as milligrams of catechin equivalents (CAE) per gram of plant material on $\mathrm{dw}$.

\subsubsection{In vitro antioxidant activity}

2.8.3.1. DPPH free radical scavenging assay. The reaction mixture, made directly on a 96 wells plate, was a solution of different sample concentrations $(30 \mu \mathrm{L})$ and methanol solution $(270 \mu \mathrm{L})$ containing DPPH radicals $\left(6 \times 10^{-5} \mathrm{~mol} / \mathrm{L}\right)$, in each well. The mixture was left to stand for $30 \mathrm{~min}$ in the dark. The reduction of the DPPH radical was determined by measuring the absorbance at $517 \mathrm{~nm}$ (Guimarães et al., 2010). A calibration curve was prepared with Trolox (linearity range: $\left.2.5-100 \mathrm{~g} / \mathrm{mL}, R^{2}>0.997\right)$. The antioxidant capacity based on the DPPH free radical scavenging ability of the extract was expressed as $\mu \mathrm{mol}$ Trolox equivalents per gram of plant material on $\mathrm{dw}$.

2.8.3.2. Ferric reducing antioxidant power (FRAP) assay. FRAP assay was carried out by the method of Benzie and Strain (Benzie \& Strain, 1999) with minor modifications. A calibration curve was prepared with ferrous sulphate (linearity range: $75-1500 \mu \mathrm{M}, R^{2}>0.999$ ), and the results were expressed as ferrous sulphate equivalents (FSE) per gram of plant material on dw.

\subsubsection{Antimicrobial assay}

2.8.4.1. Microorganisms strains. Seven bacteria and one yeast, from American Type Culture Collection (ATCC) and clinical isolates, were considered in the antimicrobial assay: Staphylococcus aureus (ATCC 6538 and a clinical isolate), S. epidermidis (clinical isolate), Escherichia coli (ATCC 8739 and a clinical isolate), Klebsiella peumoniae (ATCC 4352), Pseudomonas aeruginosa (ATCC 9027) and Candida albicans (ATCC 10231). Clinical isolates were identified to species-level with Vitek-2 identification cards and all strains were kept frozen in Brain Heart Infusion with $20 \%$ glycerol at $-70{ }^{\circ} \mathrm{C}$ until testing. For each experiment, microorganisms were subcultured twice in Nutrient agar for bacteria and Sabouraud dextrose agar for C. albicans, in order to evaluate culture viability.

2.8.4.2. MIC by broth dilution assay. Antibacterial and antifungal activities were determined according to the Clinical and Laboratory Standards Institute (CLSI) micromethods (M7-A6 and M27-A3, respectively) after $48 \mathrm{~h}$ of incubation at $37{ }^{\circ} \mathrm{C}$ (Clinical Laboratory and Standard Institute, 2003; Clinical Laboratory Standards Institute, 2008). Briefly, two-fold serial dilutions of extracts were performed in Mueller Hinton broth for bacteria and RPMI for yeast. Extracts $(10-1000 \mu \mathrm{g} / \mathrm{mL})$ were tested by comparison of microorganism's growth for each concentration with the growth control (without extract). Minimal inhibitory concentration (MIC), the lowest extract concentration able to completely inhibit microorganism growth, corresponds to $100 \%$ MIC. All determinations were performed in duplicate and corresponds to three independent experiments with concordant results.

\subsubsection{Cell culture}

Human immortalized non-tumorigenic keratinocyte cell line HaCaT (ethnicity, Caucasian; age, 62 years; gender, male and tissue, skin) was acquired from CLS Cell Lines Service, Germany. Human foreskin fibroblasts were purchased from ATCC (ATCC Number: PCS-201-012; ATCC, Manassas, VA, USA). Passage 24-26 of fibroblasts and passage 45-47 of HaCaT cells were used for both MTT assay.

HaCaT grown in RPMI (Gibco, Invitrogen Corp., USA) and fibroblasts in DMEM (Gibco, Invitrogen Corp., USA). Both mediums had GlutaMAX $^{\mathrm{TMI}}$ (Invitrogen) supplemented with FBS (10\% for keratinocytes and $15 \%$ for fibroblasts), $100 \mathrm{U} / \mathrm{mL}$ penicillin and $100 \mu \mathrm{g} / \mathrm{mL}$ streptomycin, and $0.25 \mu \mathrm{g} / \mathrm{mL}$ amphotericin $\mathrm{B}$, and were maintained in a $5 \% \mathrm{CO}_{2}$ environment at $37{ }^{\circ} \mathrm{C}$. At $90-95 \%$ confluence, both cell lines were harvested using trypsin (Invitrogen), viability assessed using the trypan blue dye exclusion assay, and re-plated in T75 flasks.

The MTT assay was performed according to the manufacturer instructions. Control was determined incubating cells with culture medium. Each concentration was tested in triplicate in three independent experiments.

\subsection{Statistical analysis of data}

Data were reported as mean \pm standard deviation of at least triplicate experiments. Statistical analysis was performed with SPSS 22.0 (SPSS Inc., Chicago, IL, USA). One-way ANOVA was used to investigate the differences between samples for all assays. Post hoc comparisons of the means were performed according to Tukey's HSD test. In all cases, $\mathrm{p}<0.05$ was accepted as denoting significance. 
Table 1 .

Chemical composition of $C$. vulgaris flower (mean \pm standard deviation). Values are average of three individual samples $(n=3)$, expressed as mean \pm standard deviation. nd - not detectable

\begin{tabular}{ll}
\hline $\begin{array}{l}\text { C. } \text { vulgaris flowers } \\
\text { Moisture }(\mathrm{g} / 100 \mathrm{~g})\end{array}$ & $12.03 \pm 0.15$ \\
Ash $(\mathrm{g} / 100 \mathrm{~g})$ & $2.31 \pm 0.09$ \\
Protein $(\mathrm{g} / 100 \mathrm{~g})$ & $6.80 \pm 0.27$ \\
Fat $(\mathrm{g} / 100 \mathrm{~g})$ & $3.70 \pm 0.10$ \\
Fiber $(\mathrm{g} / 100 \mathrm{~g})$ & $38.96 \pm 1.64$ \\
Carbohydrates $(\mathrm{g} / 100 \mathrm{~g})$ & $36.21 \pm 0.20$ \\
Vitamers $(\mathrm{mg} / 100 \mathrm{~g})$ & \\
$\alpha$-Tocopherol & $32.5 \pm 0.48$ \\
$\beta$-Tocopherol & $0.39 \pm 0.01$ \\
$\gamma$-Tocopherol & $1.19 \pm 0.06$ \\
$\delta$-Tocopherol & $0.36 \pm 0.01$ \\
$\alpha$-Tocotrienol & $\mathrm{nd}$ \\
$\beta$-Tocotrienol & $\mathrm{nd}$ \\
$\gamma$-Tocotrienol & $0.54 \pm 0.03$ \\
$\delta$-Tocotrienol & $\mathrm{nd}$ \\
Fatty acid $(\%)$ & \\
C16:0 & \\
C18:0 & $20.79 \pm 2.12$ \\
C18:1n9c & $4.55 \pm 0.56$ \\
C18:2n6c & $7.78 \pm 1.13$ \\
C20:0 $018: 3 \mathrm{n} 3$ & $27.28 \pm 1.19$ \\
C22:0 & $1.99 \pm 0.26$ \\
& $34.71 \pm 2.11$ \\
& $2.90 \pm 0.40$ \\
\hline
\end{tabular}

\section{Results}

\subsection{Macronutrient analysis}

Table 1 summarizes the nutritional composition of $C$. vulgaris flowers.

A high content of fiber $(38.96 \pm 1.64 \%)$ and carbohydrates $(36.21 \pm 0.20 \%)$ is noted. Protein represents $6.8 \%$, being also an interesting value in this concern. The comparison of $C$. vulgaris nutritional profile with the profile described for other wild plants in Portugal is of huge importance. Arbutus unedo L. (arbutus) is a wild plant that belongs to the same family of $C$. vulgaris, Ericaceae, being also present in Portugal (Pedro, 1994). Rodriguez et al.evaluated the macronutrients composition of this plant reporting that carbohydrates represents almost $20 \%$ of the nutritional content and fiber $18 \%$ (Ruiz-Rodríguez et al., 2011). Another example of a high content of fiber and carbohydrates is chestnut, presenting similar amounts and being widely spread on Portugal (Rodrigues et al., 2015). Also, when compared to green vegetables, such as chives (Allium schoenoprasum L.), coriander (Coriandrum sativum L.), mint (Mentha spicata L.) or parsley (Petroselinum crispum (Mill.) Nym), the fiber and protein content of $C$. vulgaris flowers is considerable higher (Santos et al., 2014).

\subsection{Vitamin E profile}

Vitamin $\mathrm{E}$ is one of the most important antioxidants used against oxidative stress, being the major lipid-soluble antioxidant in the cell antioxidant defense system (Kim, Decker, \& Lee, 2012). Its different constituents have antioxidant properties that result in the maintenance of cell membranes integrity due to the protective action against the lipids peroxidation. In humans, vitamin E acts as an integral part of the primary intracellular defense system and has been linked to the prevention of numerous diseases, such as cancer, cataracts, Parkinson's disease, atherosclerosis, coronary heart disease and some immune diseases (Gama, Casal, Oliveira, \& Ferreira, 2000).

Vitamin $\mathrm{E}$ consists of eight interrelated compounds, four tocopherols $(\alpha-, \beta-, \gamma-, \delta$ - tocopherol) and four tocotrienols $(\alpha-, \beta-, \gamma-, \delta$ tocotrienol). In plants, tocopherols and tocotrienols protect the chloroplast membranes from photo oxidation, providing an ideal environment for the photosynthetic process. These lipophilic compounds are synthesized by plants and vary according to the species (Gama, Casal, Oliveira, \& Ferreira, 2000).

According to Table 1 , the predominant vitamer is $\alpha$-tocopherol, being the most common form detected in photosynthetic tissues. It is the first study that reports the vitamin E profile of $C$. vulgaris, being in agreement with results reported for other Portuguese wild plants. For example, the major vitamer determined for Pterospartum tridentatum ( $9 \mathrm{mg} / 100 \mathrm{~g})$, as well as Cytisus multiflorus $(0.75 \mathrm{mg} / 100 \mathrm{~g})$, Cytisus scoparius $(\sim 11 \mathrm{mg} / 100 \mathrm{~g})$ and Cytisus striatus $(\sim 20 \mathrm{mg} / 100 \mathrm{~g})$ was $\alpha$ tocopherol (Pinela, Barros, Carvalho, \& Ferreira, 2011).

\subsection{Fatty acids profile}

Fatty acids are the principal source of energy. In the particular case of $C$. vulgaris flowers, seven fatty acids were identified (Table 1). Linolenic acid (C18:3n3, 34.7\%) was the most abundant, followed by linoleic acid (C18:2n6c, 27.3\%). These two polyunsaturated fatty acids are described in the literature as anti-inflammatory compounds, among other benefic activities (Boelsma, Hendriks, \& Roza, 2001). Palmitic acid (C16:0, 20.79\%) was the major saturated fatty acid identified. These three types of fatty acids have been reported in the early 80 's by Olechnowicz-Stepien et al. as the most representative (almost 80\%) in C. vulgaris (Olechnowicz-Stepien, Rzadkowska-Dodalska, \& Grimshaw, 1982). During fatty acids analysis, a peak eluting at similar retention time of arachidonic acid was observed. Due to the impossibility to identify the compound with the methodology used, a GC-MS identification was performed. Nonadecane was the compound present, being also identified in other plants with similar characteristics such as Calligonum azel Maire (Bannour et al., 2016).

\section{4. ${ }^{1} H$ NMR and LC-MS analysis}

In order to establish the phytochemical composition of $C$. vulgaris flowers, a multi-technique approach was used. ${ }^{1} \mathrm{H}$ NMR showed the presence of signals ascribable to sugar, namely glucose ( $\alpha$ and $\beta$ glucose signals are clearly visible at 4.90 and $4.4 \mathrm{ppm}$ ). Furthermore, signals ascribable to phenolic constituents are visible in the part of the spectrum from 6 to $7.5 \mathrm{ppm}$. In this region, signals imputable to H-6 and H-8 of flavonoids ( $\delta 6.07$ and 6.28) are clearly detectable as well as signals ascribable to $1,3,4$ trisubstitued aromatic ring (at $\delta 7.20,7.11$ and 6.70), suggesting the presence of quercetin derivatives. Intense singlet at $\delta$ 6.74 can be assigned to H-2' 6 ' of myricetin. Also, signals at $\delta 5.17-5.20$ being doublets can be due to anomeric signals of glycosidic residues and the doublet at $\delta 0.80$ can support the presence of 6-deoxy hexose as sugar residues. Fig. 1 summarise the ${ }^{1} \mathrm{H}$ NMR data. These results can support the presence of flavonoid glycosides.

Many other signals were detected and may be linked to other phytoconstituents. For this reason, LC-MS analysis was performed in order to identify and quantify several flavonoid glycosides and dimeric and trimeric procyanidins. Table 2 indicate the obtained data.

These results are different from the published by Orhan et al.that reported kaempferol-3-O- $\beta$-D-galactoside as the major flavonoid identified in C. vulgaris (Deliorman-Orhan, Şenol, Kartal, \& Orhan, 2009). In this study the most abundant derivatives were myricetin glycoside and quercetin. These flavonoids variety are probably related to enviromental conditions as well as to the possible genetic diversity of different plant population.

\subsection{Extracts characterization}

\subsubsection{TPC, TFC and antioxidant activity}

The green extraction of natural products is based on sustainable processes that employ alternative solvents, preserving at the same time products' safety and quality. The extraction efficiency of bioactive 


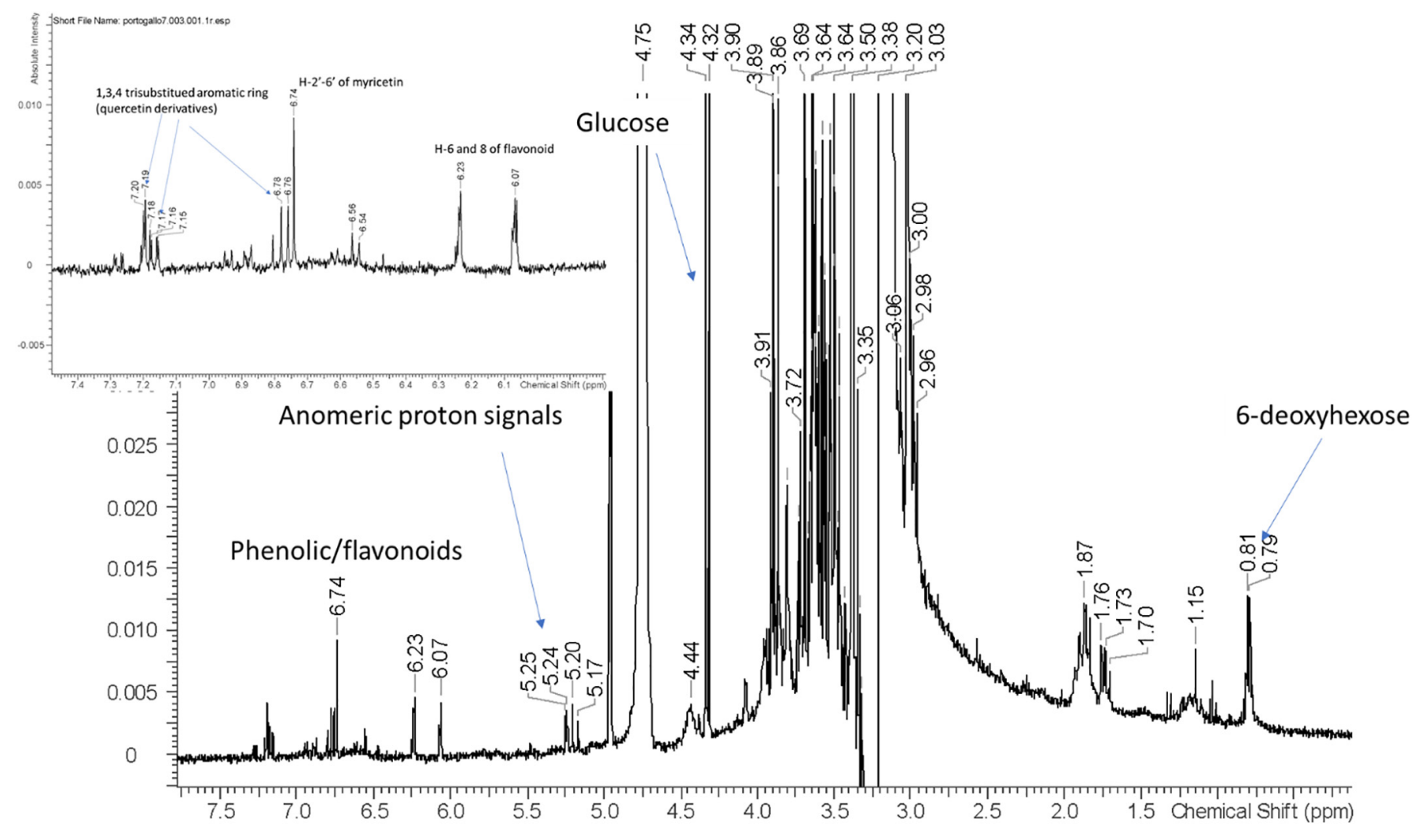

Fig. 1. ${ }^{1} \mathrm{H}$ NMR of $C$. vulgaris flowers recorded in D2O.

compounds is influenced by different factors such as time, temperature, pressure and solvents. Several solvents have been used for the extraction of phenolic compounds in C. vulgaris, namely methanol and acetone (Barros, Dueñas, Carvalho, Ferreira, \& Santos-Buelga, 2012). However, its use are not considered as safe or green. Oppositely, ethanol is recognized as a GRAS compound as it is easy to recover and reuse, being a good solution for a process that aims to be efficient and at the same time sustainable. Also, the extracts obtained may be used for different purposes without endangering human health. Based on this knowledge, in the present study water and ethanol were selected as solvents. Extraction time and temperature were established based on a previous work (Rodrigues et al., 2013).

The TPC, TFC and antioxidant activity of the different extracts are reported in Table 3.

The TPC varied from $54 \mathrm{mg}$ to $122 \mathrm{mg}$ GAE/g dw with significant differences between them $(\mathrm{p}<0.05)$. The hydro-alcoholic extract presented the highest value, probably due to solvents' polarities that determine the compounds extracted. Previous studies have compared the TPC in different types of $C$. vulgaris extracts, particularly in aerial parts of the plant (Deliorman-Orhan, Şenol, Kartal, \& Orhan, 2009). Orhan et al.reported that the TPC content is higher when ethyl acetate is used as solvent $(29.7 \pm 0.1 \mathrm{mg} \mathrm{GAE} / \mathrm{g})$, in comparison to a fraction of $n$ butanol, chloroform and water (Deliorman-Orhan, Şenol, Kartal, \& Orhan, 2009). Another study showed that the aqueous extract $(142.46 \pm 0.50 \mathrm{mg} \mathrm{GAE} / \mathrm{g}$ ) had a higher TPC value in relation to the alcoholic (81.86 $\pm 0.95 \mathrm{mg} \mathrm{GAE} / \mathrm{g})$ and ethyl acetate extracts (67.55 $\pm 0.38 \mathrm{mg} \mathrm{GAE} / \mathrm{g}$ ) (Vučić et al., 2014).

Regarding the TFC, the hydro-alcoholic extract present the highest value (118 $\mathrm{mg} \mathrm{CAE} / \mathrm{g} \mathrm{dw}$ ) followed by the aqueous one $(89 \mathrm{mg} \mathrm{CAE} / \mathrm{g}$ $\mathrm{dw}$ ). As previously described for TPC, the hydro-alcoholic extract is more effective in the flavonoid compounds extraction, probably due to polarity questions. Vucic et al.reported a variation of the TFC in the aerial parts of $C$. vulgaris, depending on the type of solvent used (aqueous, ethyl acetate and alcohol) (Vučić et al., 2014). The same research group obtained the highest TFC in the ethyl acetate extract $(64 \mathrm{mg}$ rutin/g dw).

In what concerns to DPPH assay (Table 3), the hydro-alcoholic extract presents the highest value $(52 \mu \mathrm{mol} \mathrm{TE} / \mathrm{g} \mathrm{dw})$ and the alcoholic

Table 2.

Identification and quantification of the phenolic compounds from C. vulgaris flowers by ${ }^{1} \mathrm{H}$ NMR and LC-MS analysis.

\begin{tabular}{|c|c|c|c|c|c|}
\hline No. & Rt (min) & MS $[\mathrm{M}-\mathrm{H}]^{-}$ & Fragments & Identification & Concentration $(\mu \mathrm{g} / \mathrm{g})$ \\
\hline 1 & 4.5 & 191 & $173,127,10985$ & Quinic acid & $27.07 \pm 0.11$ \\
\hline 2 & 11.0 & 863 & $711,573,451,411$ & Proanthocyanidins trimer & $25.05 \pm 0.18$ \\
\hline 3 & 11.3 & 1151 & $711,573,451,411$ & Proanthocyanidins tetramer & $8.87 \pm 0.08$ \\
\hline 4 & 12.8 & 463 & $317,287,271,179,151$ & 3,5,7,tetrahydroxy-4'-methoxy-flavanone 8-deoxyhexoside & $55.14 \pm 0.11$ \\
\hline 5 & 13.7 & 477 & 331,315 & Methoxy myricetin deoxyhexoside & $308.52 \pm 0.48$ \\
\hline 6 & 13.9 & 447 & $301,279,227,151$ & Quercetin-deoxyhexoside & $101.30 \pm 0.34$ \\
\hline 7 & 14.8 & 431 & $285,255,229,163$ & Kaempferol deoxyhexoside & $2.11 \pm 0.03$ \\
\hline 8 & 15.0 & 461 & $314,301,299,5,271,227,255$ & Myricetin deoxyhexoside & $6.39 \pm 0.08$ \\
\hline 9 & 17.5 & 301 & $273,257,179,151$ & Quercetin & $139.58 \pm 0.09$ \\
\hline 10 & 19.0 & 285 & 255,229 & Kaempferol & $15.36 \pm 0.11$ \\
\hline 11 & 20.0 & 315 & $279,179,151$ & Myricetin & $44.62 \pm 0.12$ \\
\hline \multicolumn{5}{|c|}{ Total content } & 734.01 \\
\hline
\end{tabular}


Table 3.

Total polyphenol content (TPC), total flavonoid content (TFC), abilities to scavenge DPPH free radicals and antioxidant activities based on FRAP method in the aqueous, hydro-alcoholic and alcoholic extracts of $C$. vulgaris flowers. Values are expressed as means \pm standard deviation $(n=6)$. GAE, gallic acid equivalents. CAE, catechin equivalents. Different letters (a, b, c) in the same row indicate significant differences between mean values $(\mathrm{p}<0.05)$.

\begin{tabular}{|c|c|c|c|}
\hline & \multicolumn{3}{|l|}{ Extracts } \\
\hline & Aqueous & Hydro-alcoholic & Alcoholic \\
\hline $\begin{array}{l}\text { TPC (mg GAE per } \\
\quad \mathrm{g} \mathrm{dw})\end{array}$ & $75.43 \pm 7.345^{\mathrm{b}}$ & $121.92 \pm 0.815^{\mathrm{a}}$ & $53.96 \pm 5.389^{c}$ \\
\hline $\begin{array}{l}\text { TFC (mg CAE per } \\
\text { g dw) }\end{array}$ & $88.72 \pm 1.945^{\mathrm{b}}$ & $118.26 \pm 3.598^{\mathrm{a}}$ & $14.80 \pm 1.136^{\mathrm{c}}$ \\
\hline $\begin{array}{l}\text { DPPH ( } \mu \text { mol of } \\
\text { Trolox eq. } \\
\text { per } \mathrm{g} \mathrm{dw})\end{array}$ & $23.66 \pm 0.649^{\mathrm{b}}$ & $51.83 \pm 3.903^{\mathrm{a}}$ & $15.02 \pm 1.574^{c}$ \\
\hline $\begin{array}{l}\text { FRAP }(\mu \mathrm{mol} \text { of } \\
\text { ferrous } \\
\text { sulphate per } \\
\mathrm{g} \mathrm{dw})\end{array}$ & $1354.50 \pm 102.14^{\mathrm{b}}$ & $2138.30 \pm 15.46^{\mathrm{a}}$ & $634.80 \pm 99.00^{\mathrm{c}}$ \\
\hline
\end{tabular}

extract the lowest radical inhibition capacity (15 eq $\mu \mathrm{mol} \mathrm{TE} / \mathrm{g} \mathrm{dw})$. Previous studies have also reported the significant antioxidant activity of C. vulgaris (Filip et al., 2009; D. Pavlović et al., 2014). Comparing with other species of the same family, such as Erica arborea L. and E. carnea L., its antioxidant activity is considerably higher (D. Pavlović et al., 2014; R. Pavlović, Lakušićć, Došlov-Kokoruš, \& Kovačević, 2009). The high phenolic content present in C. vulgaris flowers extracts are probably related to the high antioxidant activity described, particularly in the hydro-alcoholic extract.

The FRAP assay values ranged between 635 and $2138 \mu \mathrm{mol} \mathrm{CE} / \mathrm{g} \mathrm{dw}$ for the alcoholic and hydro-alcoholic extracts, respectively. As previously reported for the other assays, the hydro-alcoholic extract presents the highest result. This assay was previously performed on hydroalcoholic extract (with 70\% in ethanol) of $C$. vulgaris by Pavlović et al. (Pavlović et al., 2014). The significant antioxidant capacity of this species can be explained by the presence of two phenolic compounds, kaempferol-3-O- $\beta$-D-galactoside (its main flavonoid glycoside) and quercetin (Deliorman-Orhan, Şenol, Kartal, \& Orhan, 2009; Ghareeb, ElAhwany, El-mallawany, \& Saif, 2014).

\subsubsection{Pearson's correlation}

Polyphenols have been reported as responsible for the antioxidant activity of herbal extracts (Rodrigues et al., 2013). The different assays DPPH free radical scavenging and FRAP assay - were used to evaluate the antioxidant activity of $C$. vulgaris flowers extracts. These results can be correlated with TPC. A regression analysis was performed between the values of $\mu \mathrm{mol} \mathrm{TE} / \mathrm{g} d \mathrm{~d}$ sample or $\mu \mathrm{mol} \mathrm{CE} / \mathrm{g}$ dw in the antioxidant evaluation and the TPC. An extremely positive Pearson correlation were obtained for both assays, respectively $r^{2}=0.996(\mathrm{p}<0.01)$ and $r^{2}=0.963(p<0.01)$. These Pearson correlation values allow the conclusion that polyphenols are probably responsible for the antioxidant activity. Also, a regression analysis was performed between the values $\mathrm{mg}$ CAE equivalents/g dw sample and the TPC. Once again, a positive correlation $\left(r^{2}=0.899 ; \mathrm{p}<0.01\right)$ was established.

\subsubsection{Antimicrobial activity}

Different microorganisms were selected for the antimicrobial activity assay, namely Gram-positive ( $S$. aureus and $S$. epidermidis) and Gram-negative bacteria (E. coli, $K$. pneumoniae and $P$. aeruginosa) as well as fungi (C. albicans). The evaluation of antimicrobial activity of extracts can be of great relevance for different fields. In addition, microorganisms, such as fungi and bacteria, are important factors that cause oxidation processes during the products storage, leading to contaminations. Table 4 summarizes the minimal inhibitory concentrations
Table 4.

Antibacterial activity of $C$. vulgaris extracts species expressed as minimal inhibitory concentrations (MICs) in $\mathrm{mg} / \mathrm{mL}$.

\begin{tabular}{llll}
\hline \multirow{2}{*}{ Bacterial strains } & \multicolumn{2}{l}{ MIC $(\mathrm{mg} / \mathrm{mL})$} & \\
\cline { 2 - 4 } & Aqueous & Hydro-alcoholic & Alcoholic \\
\hline S. epidermidis DSM28764 & 8.8 & 2.0 & 10.8 \\
S. aureus ATCC6538 & 17.5 & 2.0 & 21.6 \\
S. aureus MRSA & 35.0 & 2.0 & 43.2 \\
P. aeruginosa ATCC9027 & $>35.0$ & $>8.5$ & $>43.2$ \\
E. coli ATCC8739 & $>35.0$ & $>8.5$ & $>43.2$ \\
K. pneumoniae ATCC4352 & $>35.0$ & $>8.5$ & $>43.2$ \\
C. albicans ATCC10231 & $>35.0$ & $>8.5$ & $>43.2$ \\
\hline
\end{tabular}

(MIC) values obtained for each microorganism.

According to Table 4, the hydro-alcoholic extract presented MIC values ranging from 2.0 to $8.5 \mathrm{mg} / \mathrm{mL}$, while the aqueous and alcoholic extracts expressed higher values for all species. The lowest MIC value was obtained with the hydro-alcoholic extract for $S$. aureus and $S$. epidermidis. The highest MIC values were obtained with the alcoholic extract in P. aeruginosa, E. coli, $K$. pneumoniae and C. albicans.

Fabry et al. stated that plant extracts can be considered as therapeutically active if MIC values are inferior to $8 \mathrm{mg} / \mathrm{mL}$ (Fabry, Okemo, \& Ansorg, 1998), while Gibbons suggests that isolated phytochemicals should have MIC values below to $1 \mathrm{mg} / \mathrm{mL}$ to present antimicrobial activity (Gibbons, 2005). The MIC values for the hydro-alcoholic extract of $S$. aureus and $S$. epidermidis were lower than $8 \mathrm{mg} / \mathrm{mL}$, indicating a possible antimicrobial effect. However, if the definition of Gibbons is considered, none of the extracts present antimicrobial activity.

The potential antimicrobial activity of $C$. vulgaris flowers extracts has been studied by different authors using other solvents. According to Kumarasamy et al., the methanolic extract presented antimicrobial activity against $S$. aureus and $S$. hominis, with a MIC value of $0.1 \mu \mathrm{g} / \mathrm{mL}$ (Kumarasamy, Cox, Jaspars, Nahar, \& Sarker, 2002). Pavlović et al. demonstrated a slight activity of the ethanolic extract (70\%) against $S$. aureus and Bacillus subtilis (D. Pavlović et al., 2014). Gharreb et al. compared the antimicrobial activity of this species with Ferula sp. and Tribulus sp., proving that the ethanolic extract of $C$. vulgaris presents antimicrobial activity against Agrobacterium tumefaciens, Erwinia sp., $K$. pneumoniae and P. aeruginosa (Ghareeb, ElAhwany, El-mallawany, \& Saif, 2014).

\subsubsection{Cell viability assay}

The different extracts of $C$. vulgaris flowers were evaluated in two cell lines, HaCaT and fibroblasts, to assess their effects on cell viability. The assays were performed with different extract concentrations: 0.1 ; 1.0; $10 ; 100$ and $1000 \mu \mathrm{g} / \mathrm{mL}$. Fig. 2(a) summarizes the obtained results in $\mathrm{HaCaT}$ cells.

As it is possible to observe, extracts did not lead to a decrease of the cell viability on this cell line until a concentration of $100 \mu \mathrm{g} / \mathrm{mL}$, remaining above $80 \%$ of viability. However, at a concentration of $1000 \mu \mathrm{g} / \mathrm{mL}$ there is a decrease in the cell viability, particularly after the exposure to aqueous extract.

Fig. 2(b) presents the results of the cell viability assay in fibroblasts. The cell viability in fibroblasts is below $100 \%$ until $100 \mu \mathrm{g} / \mathrm{mL}$. In general, these values are lower than those obtained for keratinocytes at the same concentrations. These results are in agreement with different authors that reported a higher resistance profile of $\mathrm{HaCaT}$ when compared to fibroblasts (Kempf, Kimble, \& Cuttle, 2011). However, with a concentration of $1000 \mu \mathrm{g} / \mathrm{mL}$, the cell viability is considerably higher, being statistically different. This fact may be associated with a protective effect of the extract. At higher concentrations extract's compounds can stimulate the mitochondrial activity, which may justify the cell viability observed. Nevertheless, more evidence is needed to justify this 
(a)

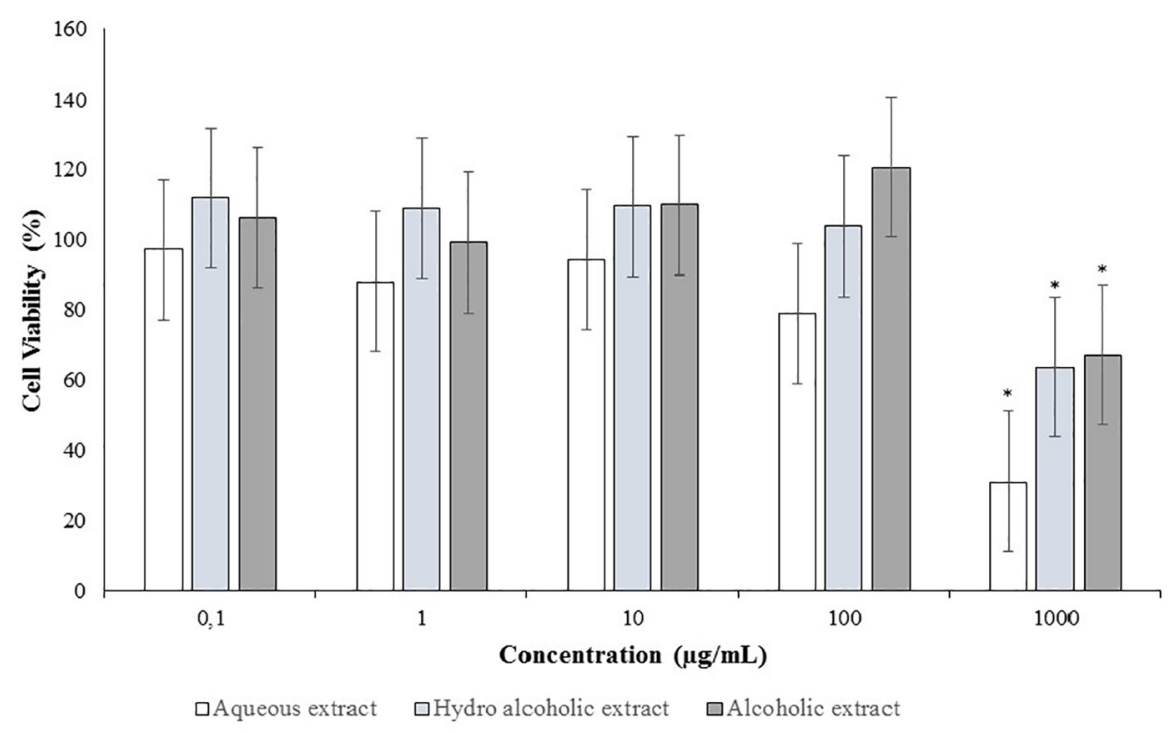

(b)

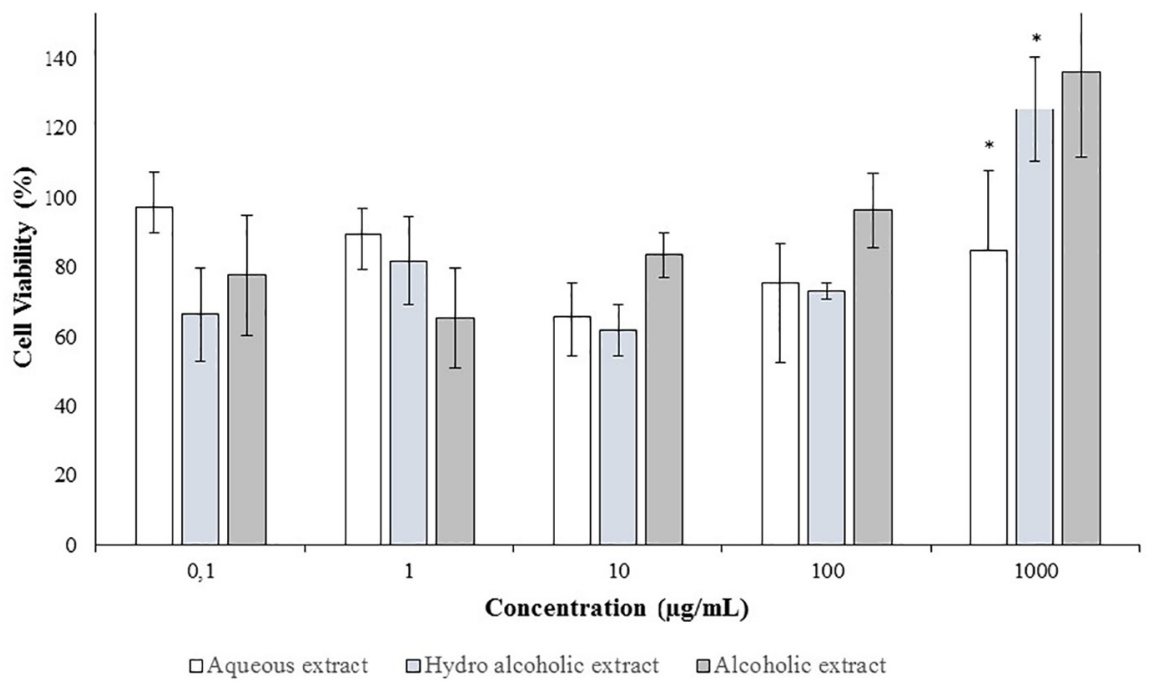

Fig. 2. Effect of aqueous, hydro-alcoholic and alcoholic extracts of $C$. vulgaris exposure on the viability of HaCaT (a) and fibroblast (b) cells at different concentrations, as measured by the MTT assay. Values are expressed as means \pm SD $(n=4)$. ${ }^{*} \mathrm{p}<0.05$ versus positive control (cells exposed to medium).

potential protective effect.

\section{Conclusions and future perspectives}

C. vulgaris flowers were characterized aiming to spread its application in food or nutraceutical industries. The nutritional analysis allowed an innovative knowledge of the macronutrient profile of heather, reporting a high content of fiber and carbohydrates. The vitamin E profile showed that the predominant vitamer was $\alpha$-tocopherol. Linolenic acid was the major fatty acid. The antioxidant activity was significant for 0 al45 extracts evaluated and positive correlations with TPC were observed. Nevertheless, the hydro-alcoholic extract presented the best results. The phytochemical analysis revealed the presence of quercetin, kaempferol and myricetin derivatives. Also, a good antimicrobial activity was observed against $S$. epidermidis and $S$. aureus with the hydro-alcoholic extract. Until a concentration of $100 \mu \mathrm{g} / \mathrm{mL}$ no decrease on cell viability in $\mathrm{HaCaT}$ cells was observed. In fibroblast, a lower cell viability was detected until $100 \mu \mathrm{g} / \mathrm{mL}$ when compared to keratinocytes. These findings indicate that $C$. vulgaris is a valuable source of health-promoting compounds and could be used as a sustainable food ingredient.

\section{Acknowledgments}

This work received financial support from the European Union (FEDER funds through COMPETE), under the partnership Agreement PT2020, and National Funds (FCT, Foundation for Science and Technology) through project LAQV/UID/QUI/50006/2013-POCI/01/ FEDER/007265. Francisca Rodrigues is thankful for her post-doc research grant from the project Operação NORTE-01-0145-FEDER000011. Diana Pinto is thankful for the research grant fromproject UID/ QUI/50006. M. Antónia Nunes and Filipa B. Pimentel are grateful to the Foundation for Science and Technology (FCT, Portugal) for the $\mathrm{PhD}$ fellowships (SFRH/BD/130131/2017 and SFRH/BD/109042/2015, respectively) financed by POPH-QREN and subsidised by the European Science Foundation and Ministério da Ciência, Tecnologia e Ensino Superior. Tânia Gonçalves Albuquerque is grateful for the $\mathrm{PhD}$ fellowship (SFRH/BD/99718/2014) funded by FCT, FSE and MEC. 
Alves, R. C., Casal, S., \& Oliviera, M. B. P. P. (2009). Determination of vitamin E in coffee beans by HPLC using a micro-extraction method. Food Science and Technology International, 15, 57-63.

Alves, R., Costa, A., Jerez, M., Casal, S., Sineiro, J., Núñez, M., \& Oliveira, M. B. (2010). Antiradical activity, phenolics profile, and hydroxymethylfurfural in espresso coffee: Influence of technological factors. Journal of Agricultural and Food Chemistry, 58(23), 12221-12229.

AOAC (2012a). Ash of flour (923.03). In W. Horwitz (Ed.). Official methods of analysis of AOAC international (pp. 2). (17th ed.). (Gaithersburg, USA).

AOAC (2012b). Fat (crude) (920.39). In W. Horwitz (Ed.). Official methods of analysis of AOAC international (pp. 33). Gaithersburg, USA.

AOAC (2012c). Nitrogen in meat (928.08). In W. Horwitz (Ed.). Official methods of analysis of AOAC international(17th ed.). Gaithersburg, USA.

AOAC (2012d). Official method of analysis of AOAC international (17th ed). .

Arabuli, G. J., Connor, S. E., \& Kvavadze, E. V. (2007). Calluna vulgaris and Spiranthes amoena in the Colchis mire flora: Weeds or relicts? Acta Palaeobotanica, 47, 469-478.

Bannour, M. Lachenmeier, D. W., Straub, I., Kohl-Himmelseher, M., Khadhri, A., AschiSmiti, S., ... Belgacem, H. (2016). Evaluation of Calligonum azel Maire, a north African desert plant, for its nutritional potential as a sustainable food and feed. Food Research International, 89, 558-564.

Barros, L., Dueñas, M., Carvalho, A. M., Ferreira, I. C. F. R., \& Santos-Buelga, C. (2012). Characterization of phenolic compounds in flowers of wild medicinal plants from northeastern Portugal. Food and Chemical Toxicology, 50(5), 1576-1582.

Benzie, I. F. F., \& Strain, J. J. (1999). Ferric reducing/antioxidant power assay: Direct measure of total antioxidant activity of biological fluids and modified version for simultaneous measurement of total antioxidant power and ascorbic acid concentration. In P. Lester (Vol. Ed.), Methods in enzymology. Vol. 299. Methods in enzymology (pp. 15-27). Academic Press.

Boelsma, E., Hendriks, H. F., \& Roza, L. (2001). Nutritional skin care: Health effects of micronutrients and fatty acids. The American Journal of Clinical Nutrition, 73(5), 853-864.

Clinical Laboratory and Standard Institute (2003). Reference method for dilution antimicrobial susceptibility tests for bacteria that grow aerobically. Wayne, Pennsylvania: NCCLS.

Clinical Laboratory Standards Institute (2008). Reference method for broth dilution antifungal susceptibility testing of yeasts. Wayne, Pennsylvania: NCCLS.

Deliorman-Orhan, D., Şenol, S., Kartal, M., \& Orhan, I. (2009). Assessment of antiradical potential of Calluna vulgaris (L.) hull and its major flavonoid. Journal of the Science of Food and Agriculture, 89(5), 809-814.

EFSA, EFSA Panel on Dietetic Products, Nutrition and Allergies (NDA) (2010). Scientific opinion on the substantiation of health claims related to live yoghurt cultures and improved lactose digestion (ID 1143, 2976) pursuant to article 13(1) of regulation (EC) no 1924/2006. EFSA Journal, 8(10), 1763-1781.

Fabry, W., Okemo, P. O., \& Ansorg, R. (1998). Antibacterial activity of east African medicinal plants. Journal of Ethnopharmacology, 60(1), 79-84.

Fernandes, T. J. R., Alves, R. C., Souza, T., Silva, J. M. G., Castro-Cunha, M., Valente, L. M. P., \& Oliveira, M. B. (2012). Lipid content and fatty acid profile of Senegalese sole (Solea senegalensis Kaup, 1858) juveniles as affected by feed containing different amounts of plant protein sources. Food Chemistry, 134(3), 1337-1342.

Filip, A., Clichici, S., Daicoviciu, D., Adriana, M., Postescu, I. D., Perde-Schrepler, M., \& Olteanu, D. (2009). Photochemoprevention of cutaneous neoplasia through natural products. Experimental Oncology, 31(1), 9-15.

Gama, P., Casal, S., Oliveira, B., \& Ferreira, M. A. (2000). Development of an HPLC/ diode-Array/Fluorimetric detector method for monitoring tocopherols and tocotrienols in edible oils. Journal of Liquid Chromatography \& Related Technologies, 23(19), 3011-3022.

García-Risco, M. R., Vázquez, E., Sheldon, J., Steinmann, E., Riebesehl, N., Fornari, T., \&
Reglero, G. (2015). Supercritical fluid extraction of heather (Calluna vulgaris) and evaluation of anti-hepatitis C virus activity of the extracts. Virus Research, 198, 9-14.

Ghareeb, D. A., ElAhwany, A. M. D., El-mallawany, S. M., \& Saif, A. A. (2014). In vitro screening for anti-acetylcholiesterase, anti-oxidant, anti-glucosidase, anti-inflammatory and anti-bacterial effect of three traditional medicinal plants. Biotechnology, Biotechnological Equipment, 28(6), 1155-1164.

Gibbons, S. (2005). Plants as a source of bacterial resistance modulators and anti-infective agents. Phytochemistry Reviews, 4(1), 63-78.

Guimarães, R., Barros, L., Barreira, J. C. M., Sousa, M. J., Carvalho, A. M., \& Ferreira, I. C. F. R. (2010). Targeting excessive free radicals with peels and juices of citrus fruits: Grapefruit, lemon, lime and orange. Food and Chemical Toxicology, 48(1), 99-106.

Kempf, M., Kimble, R. M., \& Cuttle, L. (2011). Cytotoxicity testing of burn wound dressings, ointments and creams: A method using polycarbonate cell culture inserts on a cell culture system. Burns, 37(6), 994-1000.

Kim, T. S., Decker, E. A., \& Lee, J. (2012). Antioxidant capacities of $\alpha$-tocopherol, trolox, ascorbic acid, and ascorbyl palmitate in riboflavin photosensitized oil-in-water emulsions. Food Chemistry, 133(1), 68-75.

Kumarasamy, Y., Cox, P. J., Jaspars, M., Nahar, L., \& Sarker, S. D. (2002). Screening seeds of Scottish plants for antibacterial activity. Journal of Ethnopharmacology, 83(1-2), 73-77.

Olechnowicz-Stepien, W., Rzadkowska-Dodalska, H., \& Grimshaw, J. (1982). Investigation on lipid fraction compounds of heather flowers (Calluna vulgaris L.). Polish Journal of Chemistry, 56, 153-157.

Pavlović, D., Lakušić, B., Kitić, D., Milutinović, M., Kostić, M., Miladinović, B., \& Kovačević, N. (2014). Antimicrobial activity of selected plant species of genera Arbutus 1., Bruckenthalia rchb., Calluna salisb. And Erica 1.(Ericaceae). Acta Facultatis Medicae Naissensis, 31(1), 81-85.

Pavlović, R., Lakušićć, B., Došlov-Kokoruš, Z., \& Kovačević, N. (2009). Arbutin content and antioxidant activity of some Ericaceae species. Die Pharmazie-An International Journal of Pharmaceutical Sciences, 64(10), 656-659.

Pedro, J. (1994). Carta da distribuição de figueira e medronheiro - Notícia Explicativa. Lisboa: Ministério do Ambiente e Recursos Naturais, Direcção Geral do Ambiente.

Pinela, J., Barros, L., Carvalho, A. M., \& Ferreira, I. C. F. R. (2011). Influence of the drying method in the antioxidant potential and chemical composition of four shrubby flowering plants from the tribe Genisteae (Fabaceae). Food and Chemical Toxicology, 49(11), 2983-2989.

Rodrigues, F., Palmeira-de-Oliveira, A., das Neves, J., Sarmento, B., Amaral, M. H., \& Oliveira, M. B. (2013). Medicago spp. extracts as promising ingredients for skin care products. Industrial Crops and Products, 49(0), 634-644.

Rodrigues, F., Santos, J., Pimentel, F. B., Braga, N., Palmeira-de-Oliveira, A., \& Oliveira, M. B. P. (2015). Promising new applications of Castanea sativa shell: Nutritional composition, antioxidant activity, amino acids and vitamin E profile. Food \& Function, 6(8), 2854-2860.

Ruiz-Rodríguez, B.-M., Morales, P., Fernández-Ruiz, V., Sánchez-Mata, M.-C., Cámara, M. Díez-Marqués, C., ... Tardío, J. (2011). Valorization of wild strawberry-tree fruits (Arbutus unedo L.) through nutritional assessment and natural production data. Food Research International, 44(5), 1244-1253.

Saaby, L., Rasmussen, H. B., \& Jäger, A. K. (2009). MAO-A inhibitory activity of quercetin from Calluna vulgaris (L.) hull. Journal of Ethnopharmacology, 121(1), 178-181.

Santos, J., Herrero, M., Mendiola, J., Oliva-Teles, M., Ibáñez, E., Delerue-Matos, C., \& Oliveira, M. (2014). Fresh-cut aromatic herbs: Nutritional quality stability during shelf-life. LWT-Food Science and Technology, 59(1), 101-107.

Singleton, V. L., \& Rossi, J. A. J. (1965). Colorimetry of total phenolics with phosphomolybdic-phosphotungstic acid reagents. American Journal of Enology and Viticulture, $16,144-158$.

Tontisirin, K., MacLean, W. C., \& Warwick, P. (2003). Food energy: Methods of analysis and conversion factors: Report of a technical workshop. Food and Agriculture Organization of the United Nation, Rome, Italy, 2003, 1-66.

Vučić, D. M., Petković, M. R., Rodić-Grabovac, B. B., Stefanović, O. D., Vasić, S. M., \& Čomić, L. R. (2014). In vitro activity of heather [Calluna vulgaris (L.) hull] extracts on selected urinary tract pathogens. Bosnian Journal of Basic Medical Sciences, 14(4), 234-238. 